\title{
Study on Han Embroidery Pattern of the Intangible Cultural Heritage
}

\author{
Shengli Chen \\ Wuhan Language and Culture Research Center, \\ Jianghan University, \\ Wuhan, China \\ Email: 527395960@qq.com
}

\author{
Hanjun Zhang \\ Wuhan Language and Culture Research Center, \\ Jianghan University, \\ Wuhan, China
}

\begin{abstract}
In the five thousand-year history of Chinese civilization, embroidery inherits traditional culture and national spirits. It is a product of Chinese farming culture and an important part of excellent cultural heritage of the Chinese nation. Embroidery, as a handicraft skill, has formed its own regional characteristics through its long history of accumulation and development, forming different regional folk customs. Han embroidery is one of the traditional embroidery processes with Chinese characteristics. Based on Chu embroidery, it combines the advantages of the embroidery method of North and South of China, forming distinctive local characteristics of the new system through the classification, description, and combination of the contents, forms and artistic features of Han embroidery pattern. It reveals the artistic features and causes, existing values and significance. Simultaneously, it also shows that the artistic characteristics of Han embroidery, which not only implies the aesthetic concept of "break the normal, lively first", but also reflects the artistic beauty of Chu art and deeply influences traditional Chinese aesthetic concept.
\end{abstract}

Keywords-The Intangible Cultural Heritage; Han embroidery pattern; Artistic Feature; Aesthetic Concept

\section{INTRODUCTION}

\section{A. The Intangible Cultural Heritage}

The Intangible cultural heritage refers to people of all nationalities which are inherited, and closely related to the life of a variety of traditional cultural expressions (such as folk activities, performing arts, traditional knowledge and skills, and related instruments, objects, artifacts and cultural space).The scope of intangible cultural heritage includes: poems, myths, epics, stories, legends and rhymes that have long been heard in the private sector; folk performing arts such as traditional music, dance, drama, folk art, acrobatics, puppets and shadow puppets; Life rituals, age-old activities, festivals, folk sports and athletics, as well as other customs related to production and living; folk traditional knowledge and practices concerning nature and the universe; traditional craftsmanship skills; Cultural sites and so on [1].

\section{B. Han Embroidery Pattern}

Han embroidery, one of the traditional embroidery process with Chinese characteristics, based on Chu embroidery, blending the advantage of the embroidery methods of North and South, forming a new system with a distinctive local characteristic. As a kind of embroidery species in Jingchu area, Han embroidery is vigorous, vivid and interesting. It inherits the imaginative expression and romantic artistic features of Chu embroidery. Han embroidery works filled with youthful atmosphere, especially the dragon and phoenix patterns, tiger pattern, as well as animal, plant patterns demonstrated a thriving vitality that can be called Han embroidery patterns [2]

In June 2008, Han embroidery was selected the second batch of national intangible cultural heritage protection list. The article tries to further excavate the cultural connotation of Han embroidery and explore its path of protection and development through discussing Han embroidery pattern.

\section{THE ARTISTIC FEATURES AND FORMING CAUSES OF HAN EMBROIDERY PATTERN}

\section{A. The Artistic Features of Han Embroidery Patterns}

Rich and gaudy in color. Red is the mainstream color of Chu culture, symbolizing life and enthusiasm. The silk embroidery of Chu is rich and colorful, and most of them are mainly red. The use of Han embroidery color is consistent with Chu embroidery and still uses red as the bottom color. Han embroidery thread color mainly in five colors (red, yellow, blue, white, black), and then to blue, brown, red and other heavy colors as the background, this color collocation makes the embroidery to a strong visual impact.

Han embroidery color highlights the principle of "lively first"[3], so most of the embroidery embroidered on the dark red background; The color matching on the red also emphasizes the contrast of color brightness, avoid the entire embroidery to appear dull and lifeless. Thus, the color in Han embroidery is gorgeous without fade even though the time passes. Moreover, Han Embroidery has a bright effect because of the collocation of gold and silver in Production. In the longterm practice of color-matching, Han embroidery has been accumulated a set of basic rules of color, this helps people to better understand the color-use principle of Han embroidery, 
and it is also the distinctive artistic features that make the Han embroidery more appreciative.

Variety of modeling. Han embroidery "specializes in decoration"[4], in order to achieve such artistic effect, there is whole full in composition, rich changes in local to form a strong decorative effect. There are three commonly used techniques in modeling: First, exaggerated deformation. Artists are good at splitting the traditional image of dragon and Phoenix, deformed and then re-assembled into a new form Second, bold imagination. In the work, flowers of different seasons can simultaneously open in the same plant, but also can see the life trajectory of plants from germination, flowering to fruition. Third, the strong sense of stereoscopic. Through the gradual change of color from dark to light, combined with the method of plain needle repeatedly to make the embroidered surface convex, creating a three-dimensional sense.

Changeable composition. The composition forms of Han embroidery are symmetrical, free continuous, balanced on both sides, and scattered to the point. There are two common types: one, the symmetry type, a line as the axis, left and the right side is equal. Some common auspicious patterns of Han embroidery, such as "Two dragons are playing with a pearl" is a typical symmetrical pattern. Second, the balanced type, the composition of the two sides of the body does not have to be completely equal, giving people a balanced sense of large and small, light and heavy.

Changeable stitches. The methods of using stitch is a judge of the standard of embroidery, but also the essential elements of embroidery art [5]. The ancient Han embroidery artists have created many characteristics of the stitch to form a set of basic stitch system through long-term exploration and practice, it includes the plain stitch, neat stitch, straight stitch, grabbing stitch, trocar etc. Han embroidery is mainly relied on the length of the stitch foot to form graphics, the distance is short in the process of using the stitch. Moreover, the plain stitch repeatedly layers by layer, lined up straight and smooth. As a result, embroidery looks clear and neat.

\section{B. The Forming Causes of Artistic Features}

The inheritance of folk genes in Chu culture. The inheritance of folk genes in Chu culture is the source of the artistic characteristics for Han embroidery pattern [6]. It can be seen that a large number of Chu cultural heritage are all fine shape, rich color, smooth lines, showing the Chu people worship the sun and fire, the preference for bright red. This artistic heritage can be observed from Han embroidery pattern. The inheritance of the Chu culture in the folk of Chu area includes 1) The hot, romantic and warm personality of Chu people is the internal cause for their artistic characteristics to be inherited; 2) The beauty and temperament of Chu art and its influence on the aesthetic interest of traditional Chinese society are the external causes and driving force for the inheritance of their artistic characteristics. Inheritance of such genes is difficult to shake and change.

The influence of Chinese folk customs. The formation of the artistic characteristics of Han embroidery pattern is a manifestation of folk blessings and auspicious cultural concepts [7]. According to the Han embroidery pattern, it can be seen many symbolic modeling, which reflected the blessing and auspicious culture, the formation of these patterns are influenced by Chinese folk customs, fully expressed the people's longing for Good health and safety, good fortune. It has been a part of the value of aesthetics and academic in folk arts modeling. That also reflects the Han nationality, Chu people's good hope for ample food and clothing, driving out evil spirits and so on [8].

The Influence of folk art on living environment. Han embroidery includes four categories: folk-custom products, stage stationery commodity, religious and cultural products, Folk Lantern Festival and temple fair products, etc. the needs of different categories have different specific requirements for embroidery patterns. In order to adapt to the market environment and living environment, Han embroidery developed the patterns mainly based on birds, flowers, insects and other patterns and formed a gorgeous and rich artistic feature.

\section{THE THEMES AND CONTENTS OF HAN EMBROIDERY PATTERN}

\section{A. Flower and Plant Pattern}

The Jingchu ethnic group has a splendid culture and advocates the harmonious relationship between nature and human beings. The auspicious meaning given to flowers, birds, beasts embody the Chu people to yearn for a happy life [9]. In Han embroidery patterns such as peony, pomegranate, lotus, plum, orchid, chrysanthemum and other flowers are auspicious objects that people use to express their good wishes. Peonies often are used as a symbol of wealth, which makes the entire artwork plump and vivid, meaning auspicious and rich. Han embroidery clothing and headscarves are often embroidered "rich peony" (Figure 1) to symbolize the prayer for a rich life.

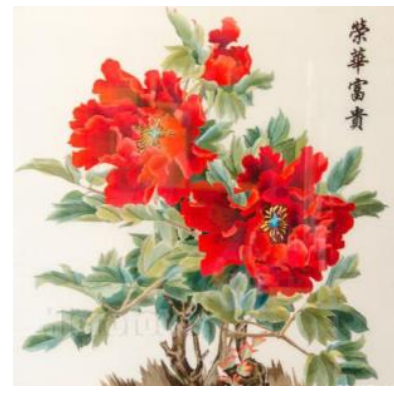

Fig. 1. The Pattern of Peony

Lotus (Figure 2) is also one of the most common patterns in Han embroidery and is often linked to people's good wishes. In daily life, lotus also symbolizes love. The lotus pattern represents "many babies" and expresses the prayer of raising children. 


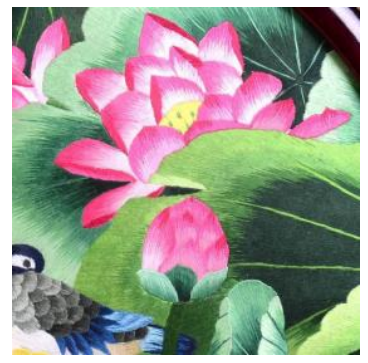

Fig. 2. The Pattern of Lotus

In addition, plum, orchid, bamboo, chrysanthemum (Figure 3), pomegranate and other patterns often appear in Han embroidery works. The natural attributes of these flowers and plants are in harmony with the spiritual attributes of human beings and they have been placed their best wishes on life.

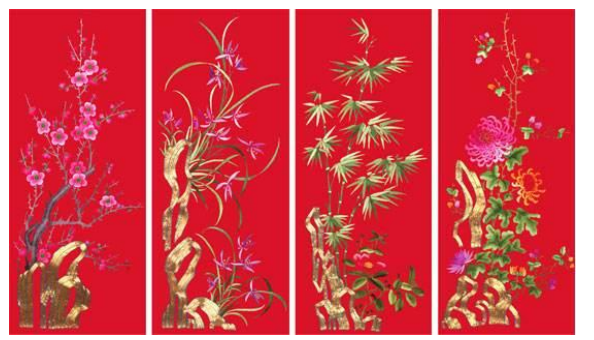

Fig. 3. The Pattern of Plum, Orchid, Bamboo, Chrysanthemum

\section{B. Animal Pattern}

Animal patterns in the Jingchu area are related to primitive tribal totem symbols. As a folk art, Han embroidery also used a variety of animal patterns, of which the dragon, phoenix pattern is the most prominent. Phoenix is the totem of Chu ancestors with a long history in Jingchu, in particular, there are many performances of Phoenix in $\mathrm{Chu}$ embroidery to symbolize peace, and tranquility.it can be observed that Phoenix appears with single Phoenix (Figure 4), double Phoenix, group Phoenix and other different forms. Phoenix has different poses in Han embroidery works, such as a big leap or fly, holding head high, show happy and romantic, also symbolizes the energetic spirit and character.

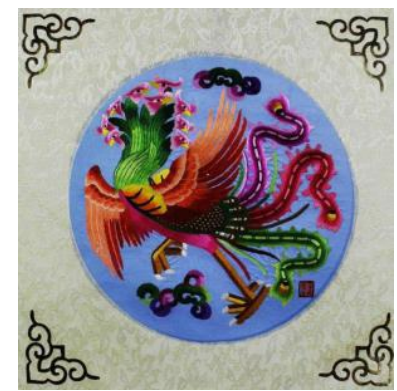

Fig. 4. The Pattern of Single Phoenix

The Dragon (Figure 5) in Jingchu folk was meaning for the auspicious and wealth, longevity, often appear in Chu embroidery works. The combination of dragon pattern and phoenix pattern (Figure 6) is a symbol of happy life, but also contains the combination of Yin and Yang of traditional Chinese culture.

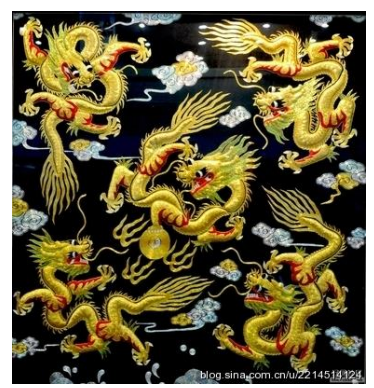

Fig. 5. The Pattern of Dragon

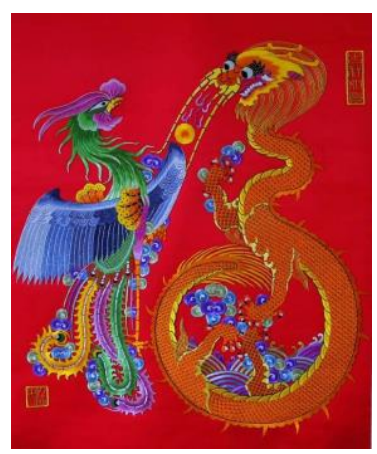

Fig. 6. The Pattern of "Dragon and Phoenix"

\section{Figure Pattern}

The themes of figures pattern in Han embroidery include mythological (Figure 7), the statue of Buddha, the hero, etc. The embroidery style is still vivid and rich in decoration. The figures of the golden thread in the Han Embroidery is also a great feature. Using the golden thread in the embroidery can make it concise, full and vivid. In the long period of artistic practice, Han Embroidery has also formed a unique embroidered technique to the head of the figure pattern. It is the combination of a variety of stitches done on the facial features, which is also rare in the embroidered species in other places. Compared to the oil-like texture of Su embroidery, then Han embroidery characters are bold to the emphasis on freehand expressive.

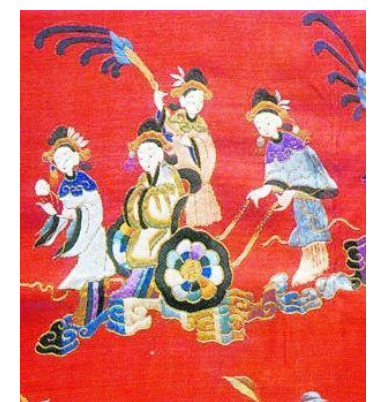

Fig. 7. The Pattern of Characters of Mythological 


\section{Text pattern}

Text pattern is the use of Chinese characters as decorative patterns to show the artistic charm of embroidery, which is a prominent feature different from other local embroideries. It is common in many works of Han embroidery that the flowers such as peony, chrysanthemum, and rose are filled in the glyphs of Chinese auspicious characters. There are a simple embroidered words, repetitive embroidered words, and combinations of words and flowers. The unique combination of flowers and characters demonstrate a specific style because of rich color, distinct conception. For example, in the pattern of "Fu" (Figure 8), all kinds of exotic flowers and plants are filled in, all of which are used to symbolize auspicious festivities and express the longing for the common people to live a better life. This manipulation technique has also become an artistic feature that distinguishes Han embroidery from other local embroidery species.

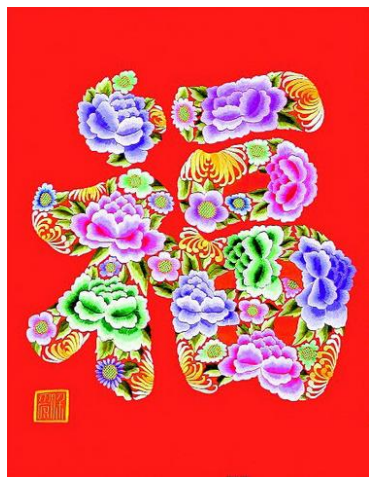

Fig. 8. The Pattern of "FU"

Auspicious patterns, flowers, mascot and other items are used to compose of embroidery in Han embroidery, through the combination of graphic and characters, the moral meaning of the text can be seen in visual. Its performance in two ways: one is full of flora and fauna filled in the glyph. The other is the text looming interspersed between animal and plant patterns. In daily life, the ornaments, such as "Fu, Lu, Shou, and $\mathrm{Xi"}$ (Figure 9), are often used in door curtains, sheets, and curtains. Even simple characters can also become very distinctive through meticulous embroidery. These originalities of "flower words" make people more Intuitive to aware of Han Embroidery.
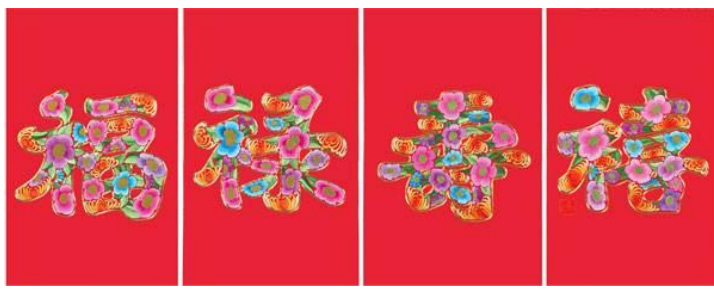

Fig. 9. The Pattern of Fu, Lu, Shou, and Xi

\section{HAN EMBROIDERY PATTERNS OF VALUE}

According to historical records, Han embroidery began in Han Dynasty, bloomed in Tang Dynasty. In the middle of the Qing Dynasty, it reaches its peak in Wuhan, although its history was only a few hundred years; but it traced back to the source for more than two thousand years. As a traditional craft of Wuhan and Chu culture legacy, Han embroidery pattern has special value and significance of the research.

Chu culture fossils. According to Jing Chu customs and culture needs, Han embroidery pattern creates a warm and strong atmosphere, these directly uphold the romantic, curious emotional characteristics of Jingchu people. It is of great significance to study the pattern of Han embroidery in preservation, circulation, and evolution of Chu culture in the folk. It is also the living fossil of studying the development and change of $\mathrm{Chu}$ culture from farming society to modernization.

Innovation. Han embroidery pattern has the artistic features with rich color, strong decorative, bold ideas, delicately embroidery. Researching Han embroidery patterns has an important reference to the development of the Contemporary patterns, based on it, designers can devise more and better beautiful patterns for the people of the Chu region.

Appreciation and collection. The study of Han embroidery patterns with never "fading" charm will enable people to get their unique ornamental value. Han embroidery is magnificent and elegant, it is rich in the stereoscopic and virtual sense, and the visual impact is very strong. It uses the dark color to make the bottom color, the works are completely unfading and has high appreciation value and collection significance.

\section{CONCLUSION}

The composition, coloring, modeling, and stitch of Han embroidery patterns are very different from those of other embroidered ones, which greatly maintain the pure quality of Han Embroidery from the folk, without losing the elegant of Chu culture elegant, the rich of Han embroidery and other artistic features. In recent years, traditional patterns are more and more widely used in modern design, which also brings opportunities to the inheritance and innovation of Han embroidery. Combining the elements of Han embroidery with the modern design principles to create contemporary Han embroidery pattern that embodies a strong regional culture and a strong modern flavor will surely be favored by today's consumers who pursue personality and fashion, providing the possibility to find a new path of Embroidery market. Therefore, to study the design of Han embroidery pattern has important practical significance for its preservation and development, and is also the fundamental reason for carrying forward the quintessence of national culture. 


\section{ACKNOWLEDGMENT}

This work is supported by "The art innovation of Wuhan colleges and universities from the perspective of intangible cultural heritage, NO. Z12" which is granted by Hubei Provincial Education Department, Wuhan, China, in 2015.

\section{REFERENCES}

[1] https://baike.baidu.com/item/Intangible Cultural/3591789.

[2] https://baike.baidu.com/item/pattern/52183.

[3] Feng Zemin. Jing Chu Han embroidery [M]. Wuhan Publishing House, 2012. (In Chinese)

[4] Feng Zemin. Han embroidery and intangible cultural heritage [M]. Wuhan Publishing House, 2011. (In Chinese)

[5] Liu Kuili. Zhang Xu. "Chinese Folk Culture Series - Embroidery." China Social Press, 2007. (In Chinese)

[6] Wang Zulong. "Chu art concepts and morphology." Sichuan Publishing Group. (In Chinese)

[7] Zhang Blossoming. "Embroidery Writing - An Analysis of Chinese Embroidery Art." Literary and Art Research. 2006 (12). (In Chinese)

[8] Li Qun, "The Development of Traditional Embroidery from Practicality and Aesthetic Appreciation." Commercial Culture (Academic Version). 2008-01. (In Chinese)

[9] Yin Junyan. On the modeling characteristics of folk art Turitu embroidery patterns as an example. "Chinese Tu. 2008 04. (In Chinese) 